\title{
SYNTHESIS, CHARACTERIZATION AND ANTIMICROBIAL ACTIVITY OF SOME TRANSITION METAL COMPLEXES OF N-(5-CHLORO-2-HYDROXYPHENYL)-3- METHOXY-SALICYLALDIMINE
}

\author{
Demet Gürbüz ${ }^{1}$, Adem Çinarli ${ }^{1}$, Aydin Tavman ${ }^{1, *}$ and A. Seher Birteksöz Tan ${ }^{2}$ \\ ${ }^{1}$ Istanbul University, Faculty of Engineering, Department of Chemistry, 34320, Avcilar, \\ Istanbul, Turkey \\ ${ }^{2}$ Istanbul University, Faculty of Pharmacy, Department of Pharmaceutical Microbiology, 34452, \\ Beyazit, Istanbul, Turkey
}

(Received August 5, 2013; revised November 9, 2014)

\begin{abstract}
Cr(III), Fe(II), Fe(III), Co(II), Ni(II), Cu(II), Zn(II) complexes of $N$-(5-chloro-2-hydroxyphenyl)3-methoxy-salicylaldimine $\left(\mathrm{H}_{2} \mathrm{~L}\right)$, an ONO type tridentate ligand, were synthesized and characterized by elemental analysis, magnetic moment, molar conductivity, TGA, NMR, IR, UV-vis. and ESI-MS spectral techniques. All of the complexes except $\left[\mathrm{Zn}(\mathrm{L})\left(\mathrm{H}_{2} \mathrm{O}\right)_{2}\right]$ are paramagnetic. The $\mathrm{CoCl}_{2}$ gives a complex with 1:2 M:L ratio while the others form 1:1 non-ionic complexes with $\mathrm{H}_{2} \mathrm{~L}$. The ligand coordinated to the metal ions through the both $\mathrm{OH}$ oxygen and the azomethine nitrogen atoms acting tridentate behaviour. Octahedral geometry has been proposed for the $\mathrm{Fe}(\mathrm{II}), \mathrm{Cr}(\mathrm{III}), \mathrm{Co}(\mathrm{II}), \mathrm{Ni}(\mathrm{II})$ complexes considering the magnetic moment values and the electronic spectral data. The $\mathrm{Zn}$ (II) and $\mathrm{Fe}(\mathrm{III})$ complexes exhibit five coordination geometries and the $\mathrm{Cu}$ (II) complex is four-coordinated having acetato bridged dimeric structure. Antimicrobial activities of the compounds were determined against six bacteria and C. albicans as fungi. The $\mathrm{Ni}(\mathrm{II})$ and $\mathrm{Co}(\mathrm{II})$ complexes exhibit considerable selective activity on $S$. epidermidis and C. albicans whereas the ligand has no activity on the microorganisms. In addition, the $\mathrm{Cr}(\mathrm{III})$ complex shows antibacterial activity toward S. epidermidis and the $\mathrm{Zn}(\mathrm{II})$ complex has antifungal activity on C. albicans.
\end{abstract}

KEY WORDS: Schiff base, Salicylaldimine, 5-Chloro-2-hydroxyphenyl, Transition metal complexes, Antimicrobial

\section{INTRODUCTION}

Salicylaldimines are known the $o$-hydroxy derivatives of Schiff bases and they are of particular interest due to an asymmetric intramolecular hydrogen bond formed between the oxygen and nitrogen atoms [1,2]. Transition metal complexes with these types Schiff bases are of particular interest because of their ability to possess unusual configurations, be structurally labile and their sensitivity to molecular environments [3-5]. They have wide applications in fields such as antibacterial, antiviral, antifungal agents [6], homogeneous or heterogeneous catalysis [7]. Schiff bases are potential anticancer drugs [8] and when administered as their metal complexes, the anticancer activity of these complexes is enhanced in comparison to the free ligand [9]. It has been shown that Schiff base complexes derived from 4-hydroxysalicylaldehyde and amines have strong anticancer activity, e.g., against Ehrlich ascites carcinoma (EAC) [10,11]. A large number of Schiff bases and their complexes have been investigated for their interesting and important properties, such as their ability to reversibly bind oxygen, catalytic activity in the hydrogenation of olefins, photochromic properties and complexing ability towards some toxic metals, furthermore complexes of Schiff bases showed promising applications in biological activity and biological modeling applications [12]. It was reported that complexes of Schiff bases have been used as antibacterial, antifungal, anticancer, antitubercular, hypertensive, and hypothermic reagents [13].

In this study $\mathrm{Cr}(\mathrm{III}), \mathrm{Fe}(\mathrm{II}), \mathrm{Fe}(\mathrm{III}), \mathrm{Co}(\mathrm{II}), \mathrm{Ni}(\mathrm{II}), \mathrm{Cu}(\mathrm{II}), \mathrm{Zn}(\mathrm{II})$ complexes of $N$-(5-chloro2-hydroxyphenyl)-3-methoxy-salicylaldimine $\left(\mathrm{H}_{2} \mathrm{~L}\right)$ (Figure 1) were synthesized and characterized. Antimicrobial activity of the compounds was evaluated against six bacteria and Candida albicans as fungus.

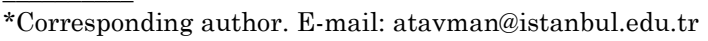




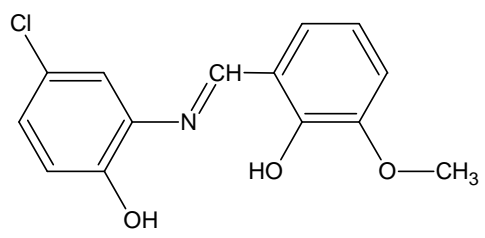

Figure 1 . The chemical structure of $N$-(5-chloro-2-hydroxyphenyl)-3-methoxy-salicylaldimine.

\section{EXPERIMENTAL}

All chemicals and solvents were of reagent grade and were used without further purification. Elemental analysis data were obtained with a Thermo Finnigan Flash EA 1112 analyzer. Melting points were determined using an Electro thermal melting-point apparatus. ${ }^{1} \mathrm{H}$ - and ${ }^{13} \mathrm{C}$ NMR spectra were run on a Varian Unity Inova 500 NMR spectrometer. The residual DMSO- $\mathrm{d}_{6}$ signal was also used as an internal reference. FT-IR spectra were recorded in $\mathrm{KBr}$ disks on a Mattson 1000 FT-IR spectrometer. UV-Visible spectra was performed on a Perkin Elmer Lambda $25 \mathrm{UV} /$ Visible Spectrometer in $\mathrm{MeOH}$. The Electron Spray Ionization-Mass Spectroscopy (ESI-MS) analyses were carried out in positive ion modes using a Thermo Finnigan LCQ Advantage MAX LC/MS/MS. Magnetic moments of the paramagnetic complexes were carried out on a Sherwood Scientific apparatus (MK1) at room temperature by Gouy's method. Molar conductivity of the complexes was measured on a WTW Cond315i conductivity meter in dimethyl formamide (DMF) at $25{ }^{\circ} \mathrm{C}$. Thermogravimetric studies were made on a TG-60WS Shimadzu, with a heating rate of $10^{\circ} \mathrm{C} / \mathrm{min}$ and air flowing at the rate of $50 \mathrm{~mL} / \mathrm{min}$.

Synthesis of the ligand $\left(\mathrm{H}_{2} \mathrm{~L}\right)$

$\mathrm{H}_{2} \mathrm{~L}$ was prepared by mixing an ethanolic solution $(15 \mathrm{~mL})$ of 4-chloro-2-aminophenol (1.44 g, $10 \mathrm{mmol})$ with 3-methoxy-salicylaldehyde $(1.52 \mathrm{~g}, 10 \mathrm{mmol})$ in same volume of ethanol. This mixture was then refluxed with stirring for $3 \mathrm{~h}$ and the solution was allowed at the room temperature to crystallize $\mathrm{H}_{2} \mathrm{~L}$ [1].

Syntheses of the complexes: general procedure

$100 \mathrm{mg}$ ligand $(0.36 \mathrm{mmol})$ and equivalent amounts of metal salts (e.g. $96 \mathrm{mg} \mathrm{CrCl}_{3} \cdot 6 \mathrm{H}_{2} \mathrm{O}, 0.36$ $\mathrm{mmol})$ were dissolved in ethanol $(20 \mathrm{~mL})$ and the mixture was refluxed for $4 \mathrm{~h}$. The mixture was allowed to stand at room temperature for a few days. Then the precipitate formed was filtered and washed with ethanol $(2 \mathrm{~mL})$ and diethylether $(5 \mathrm{~mL})$ and dried at room temperature. The other complexes were obtained similarly. The salts used for synthesis of the complexes are: $\mathrm{CrCl}_{3} \cdot 6 \mathrm{H}_{2} \mathrm{O}, \mathrm{FeSO}_{4} \cdot 7 \mathrm{H}_{2} \mathrm{O}, \mathrm{FeCl}_{3} \cdot 6 \mathrm{H}_{2} \mathrm{O}, \mathrm{CoCl}_{2} \cdot 6 \mathrm{H}_{2} \mathrm{O}, \mathrm{NiCl}_{2} \cdot 6 \mathrm{H}_{2} \mathrm{O}, \mathrm{Cu}\left(\mathrm{CH}_{3} \mathrm{COO}\right)_{2} \cdot \mathrm{H}_{2} \mathrm{O}$ and $\mathrm{Zn}\left(\mathrm{CH}_{3} \mathrm{COO}\right)_{2} \cdot 2 \mathrm{H}_{2} \mathrm{O}$.

\section{Determination of antimicrobial activity}

Antimicrobial activity against Staphylococcus aureus ATCC 6538, Staphylococcus epidermidis ATCC 12228, Escherichia coli ATCC 8739, Klebsiella pneumoniae ATCC 4352, Pseudomonas aeruginosa ATCC 27853, Proteus mirabilis ATCC 14153 and Candida albicans ATCC 10231 were determined by the microbroth dilutions technique following the Clinical and Laboratory Standards Institute (CLSI) recommendations [14, 15]. Mueller-Hinton broth for bacteria, RPMI1640 medium buffered to $\mathrm{pH} 7.0$ with MOPS for yeast strain was used as the test medium. Serial two-fold dilutions ranging from $5000 \mu \mathrm{g} / \mathrm{mL}$ to $4.9 \mu \mathrm{g} / \mathrm{mL}$ were prepared in medium. The 
inoculum was prepared using a 4-6 h broth culture of each bacteria and 24 culture of yeast strains adjusted to a turbidity equivalent to a $0.5 \mathrm{McF}$ arland standard, diluted in broth media to give a final concentration of $5 \times 10^{5} \mathrm{cfu} / \mathrm{mL}$ for bacteria and $0.5 \times 10^{3}$ to $2.5 \times 10^{3} \mathrm{cfu} / \mathrm{mL}$ for yeast in the test tray. The trays were covered and placed in plastic bags to prevent evaporation. The trays containing Mueller-Hinton broth were incubated at $35{ }^{\circ} \mathrm{C}$ for $18-20 \mathrm{~h}$ and the trays containing RPMI-1640 medium were incubated at $35{ }^{\circ} \mathrm{C}$ for $46-50 \mathrm{~h}$. The minimum inhibitory concentrations (MIC) were defined as the lowest concentration of compound giving complete inhibition of visible growth. Antimicrobial effects of the solvents were investigated against test microorganisms. The medium with DMSO as solvent was used as a negative control whereas media with Ciprofloxacin (standard antibiotic) and Fluconazole (standard antifungal drug) were used as the positive controls. The experiments were performed in triplicate.

\section{General properties}

\section{RESULTS AND DISCUSSION}

In this study, $\mathrm{Cr}(\mathrm{III}), \mathrm{Fe}(\mathrm{II}), \mathrm{Fe}(\mathrm{III}), \mathrm{Co}(\mathrm{II}), \mathrm{Ni}(\mathrm{II}), \mathrm{Cu}(\mathrm{II})$ and $\mathrm{Zn}(\mathrm{II})$ complexes of $N$-(5-chloro2-hydroxyphenyl)-3-methoxy-salicylaldimine $\left(\mathrm{H}_{2} \mathrm{~L}\right)$, an ONO type tridentate ligand, were synthesized and characterized by elemental and thermal analyses, magnetic moment, molar conductivity measurements and NMR, IR, UV-Vis, ESI-MS spectral techniques. The data of the ligand were reported in our previous study [1a]. The analytical data and physical properties of the ligand and the complexes are summarized in Table 1. The complexes are paramagnetic except $\left[\mathrm{Zn}(\mathrm{L})\left(\mathrm{H}_{2} \mathrm{O}\right)_{2}\right]$ and they have 1:1 M:L ratio except that of $\mathrm{Co}(\mathrm{II})$. Molar conductivity of the complexes showed that all complexes are non-electrolytes in DMF (Table 1).

Table 1. The analytical data and physical properties of the ligand and the complexes.

\begin{tabular}{|c|c|c|c|c|c|c|c|c|}
\hline \multirow[t]{2}{*}{ Compound } & \multicolumn{3}{|c|}{$\begin{array}{c}\text { Elemental analysis } \\
\text { found (calcd) } \%\end{array}$} & \multirow{2}{*}{$\begin{array}{l}\mathrm{Y} \\
\%\end{array}$} & \multirow{2}{*}{${ }^{\mathrm{m}} \mathrm{C} . \mathrm{C}}$. & \multirow{2}{*}{$\begin{array}{l}\mu_{\text {eff }} \\
\text { BM }\end{array}$} & \multirow[t]{2}{*}{$\Lambda$} & \multirow[t]{2}{*}{ Color } \\
\hline & $\mathrm{C}$ & $\mathrm{H}$ & $\mathrm{N}$ & & & & & \\
\hline $\begin{array}{l}\mathrm{H}_{2} \mathrm{~L} \\
\mathrm{C}_{14} \mathrm{H}_{12} \mathrm{ClNO}_{3}\end{array}$ & $\begin{array}{r}60.19 \\
(60.55) \\
\end{array}$ & $\begin{array}{c}4.64 \\
(4.36) \\
\end{array}$ & $\begin{array}{c}5.03 \\
(5.04) \\
\end{array}$ & 87 & 210 & 0 & -- & Brick red \\
\hline $\begin{array}{l}{\left[\mathrm{Cr}(\mathrm{L}) \mathrm{Cl}\left(\mathrm{H}_{2} \mathrm{O}\right)_{2}\right] \cdot 4 \mathrm{H}_{2} \mathrm{O}} \\
\mathrm{C}_{14} \mathrm{H}_{22} \mathrm{Cl}_{2} \mathrm{CrNO}_{9}\end{array}$ & $\begin{array}{c}35.73 \\
(35.68)\end{array}$ & $\begin{array}{c}4.38 \\
(4.71) \\
\end{array}$ & $\begin{array}{c}3.21 \\
(2.97)\end{array}$ & 75 & 207 & 3.65 & 36 & $\begin{array}{c}\text { Dark } \\
\text { brown }\end{array}$ \\
\hline $\begin{array}{l}{\left[\mathrm{Fe}(\mathrm{L})\left(\mathrm{H}_{2} \mathrm{O}\right)_{3}\right]} \\
\mathrm{C}_{14} \mathrm{H}_{16} \mathrm{ClFeNO}_{6}\end{array}$ & $\begin{array}{c}43.52 \\
(43.61) \\
\end{array}$ & $\begin{array}{c}3.80 \\
(4.18) \\
\end{array}$ & $\begin{array}{c}3.60 \\
(3.63) \\
\end{array}$ & 86 & $>400$ & 5.18 & 9.0 & Black \\
\hline $\begin{array}{l}{\left[\mathrm{Fe}(\mathrm{L})\left(\mathrm{H}_{2} \mathrm{O}\right)(\mathrm{OH})\right]} \\
\mathrm{C}_{14} \mathrm{H}_{13} \mathrm{ClFeNO}_{5}\end{array}$ & $\begin{array}{c}45.42 \\
(45.87) \\
\end{array}$ & $\begin{array}{c}3.88 \\
(3.57)\end{array}$ & $\begin{array}{c}3.67 \\
(3.82) \\
\end{array}$ & 77 & $>400$ & 4.70 & 16 & Black \\
\hline $\begin{array}{l}\left.\mathrm{Co}(\mathrm{HL})_{2}\right] \cdot 2 \mathrm{H}_{2} \mathrm{O} \\
\mathrm{C}_{28} \mathrm{H}_{26} \mathrm{Cl}_{2} \mathrm{CoN}_{2} \mathrm{O}_{8}\end{array}$ & $\begin{array}{c}52.10 \\
(51.87)\end{array}$ & $\begin{array}{c}3.94 \\
(4.04)\end{array}$ & $\begin{array}{c}4.67 \\
(4.32) \\
\end{array}$ & 70 & 204 & 5.13 & 27 & $\begin{array}{l}\text { Reddish } \\
\text { brown }\end{array}$ \\
\hline $\begin{array}{l}\left.\mathrm{Ni}(\mathrm{L})\left(\mathrm{H}_{2} \mathrm{O}\right)_{3}\right] \\
\mathrm{C}_{14} \mathrm{H}_{16} \mathrm{ClNiNO}_{6} \\
\end{array}$ & $\begin{array}{c}43.73 \\
(43.29) \\
\end{array}$ & $\begin{array}{c}3.87 \\
(4.15) \\
\end{array}$ & $\begin{array}{c}3.24 \\
(3.61) \\
\end{array}$ & 84 & $>400$ & 3.37 & 15 & Light brown \\
\hline $\begin{array}{l}{\left[\mathrm{Cu}_{2}(\mathrm{HL})(\mathrm{L})(\mathrm{Ac})\right]} \\
\mathrm{C}_{30} \mathrm{H}_{24} \mathrm{Cl}_{2} \mathrm{Cu}_{2} \mathrm{~N}_{2} \mathrm{O}_{8}\end{array}$ & $\begin{array}{c}48.79 \\
(48.79) \\
\end{array}$ & $\begin{array}{c}3.69 \\
(3.28) \\
\end{array}$ & $\begin{array}{c}4.06 \\
(3.79) \\
\end{array}$ & 61 & 387 & 1.38 & 2.3 & $\begin{array}{l}\text { Army } \\
\text { green }\end{array}$ \\
\hline $\begin{array}{l}\left.\mathrm{Zn}(\mathrm{L})\left(\mathrm{H}_{2} \mathrm{O}\right)_{2}\right] \\
\mathrm{C}_{14} \mathrm{H}_{14} \mathrm{ClNO}_{5} \mathrm{Zn}\end{array}$ & $\begin{array}{c}44.88 \\
(44.59)\end{array}$ & $\begin{array}{c}3.96 \\
(3.74)\end{array}$ & $\begin{array}{c}3.67 \\
(3.71) \\
\end{array}$ & 92 & $>400$ & 0 & 0.3 & Dark yellow \\
\hline
\end{tabular}

$\mathrm{Y}$, Yield; $\mu_{\text {eff }}$, effective magnetic moment; $\Lambda$, Molar conductivity, $\Omega^{-1} \mathrm{~cm}^{2} \mathrm{~mol}^{-1}\left(25 \pm 1^{\circ} \mathrm{C}\right)$.

Melting points of the $\mathrm{Cr}(\mathrm{III})$ and $\mathrm{Co}(\mathrm{II})$ complexes are lower than that of the others. Relatively lower melting point of the $\mathrm{Cr}(\mathrm{III})$ complex, $\left[\mathrm{Cr}(\mathrm{L}) \mathrm{Cl}\left(\mathrm{H}_{2} \mathrm{O}\right)_{2}\right] \cdot 4 \mathrm{H}_{2} \mathrm{O}$, may be resulted from its' high water content coordinated and uncoordinated. The Co(II) complex, $\left[\mathrm{Co}(\mathrm{HL})_{2}\right] \cdot 2 \mathrm{H}_{2} \mathrm{O}$, has $1: 2 \mathrm{M}: \mathrm{L}$ ratio as a difference from the others. Also, this complex compound has lower melting point degree according to the others except the $\mathrm{Cr}$ (III) complex. This situation can be explained as follows: Probably only one of the $\mathrm{OH}$ protons is removed on 
complexation and a complex compound is formed in $\left[\mathrm{Co}(\mathrm{HL})_{2}\right]$ form. This type complex may be has lower thermal stability according to the others; and the lower melting point of $\mathrm{Co}$ (II) complex may be related to its structure. Similarly, higher molar conductivity of $\mathrm{Co}$ (II) complex than expected may be related with $\mathrm{OH}$ coordination, also. The following weak dissociation should be occured when the Co(II) complex is dissolved in DMF: $\left[\mathrm{Co}(\mathrm{HL})_{2}\right] \leftrightarrows\left[\mathrm{Co}(\mathrm{L})_{2}\right]^{2-}+2 \mathrm{H}^{+}$ [16]. As a result of this dissociation, the molar conductivity of the Co(II) complex is higher than the expected. According to the molar conductivity measurements all of the complexes have nonionic character.

The Fe(II) and Ni(II) complexes are very similar to each other structurally. The coordination number of these complexes is 6. Probably, geometry of the Fe(II) and Ni(II) complexes is distorted octahedral. The $\mathrm{FeCl}_{3}$ gave a hydroxo complex having ampirical formula $\left[\mathrm{Fe}(\mathrm{L})\left(\mathrm{H}_{2} \mathrm{O}\right)(\mathrm{OH})\right]$. Presence of a hydroxyl ion is due to the hydrolysing of $\mathrm{Fe}(\mathrm{III})$ salt. It is known that $\mathrm{Fe}(\mathrm{III})$ salts hydrolyses easily above $\mathrm{pH} 5$ and thus, this easy hydrolysis leads to the formation of hydroxo complexes [17]. Elemental analysis and ESI-MS spectral analysis results are in agreement with the suggested composition formulas of the complexes (Tables 1 and 5).

\section{Magnetic moments}

Room temperature magnetic moment values of the solid complexes are presented at Table 1 . Magnetic moment value of the Fe(III) complex, 4.70 BM, indicates stabilization of the species having intermediate ferric spin $(\mathrm{S}=3 / 2)$ state. The occurrence of such an intermediate spin state is typical for the six and five coordinate ferric complexes [18]. The magnetic moment of the $\mathrm{Fe}(\mathrm{II})$ complex, $\mu=5.18 \mathrm{BM}$, is in the range for the high spin $\mathrm{Fe}$ (II) state [19].

The $\mathrm{Cr}(\mathrm{III})$ complex shows magnetic moment $(3.65 \mathrm{BM})$ corresponding to three unpaired electrons, i.e. 3.72 BM, expected for high-spin octahedral $\mathrm{Cr}$ (III) complexes [20].

Observed magnetic moment value for the Co(II) complex at room temperature is $5.13 \mathrm{BM}$. This value can be considered as characteristic of complexes with an high-spin octahedral environment around $\mathrm{Co}$ (II) in the range 4.7-5.2 BM [21]. It is known that both tetrahedral and high-spin octahedral $\mathrm{Co}$ (II) complexes possess three unpaired electrons but may be distinguished by the magnitude of the deviation of $\mu_{\mathrm{eff}}$ from the spin-only value. The magnetic properties of high spin octahedral Co(II) complexes are governed by the orbitally degenerate ground term ${ }^{4} \mathrm{~T}_{1 g}$; this provides an orbital contribution to the magnetic moment so that room temperature moments are experimentally found to be in the range 4.7-5.2 $\mathrm{BM}[18,21,22]$.

Magnetic moment value for the $\mathrm{Ni}$ (II) complex is $3.37 \mathrm{BM}$, which is near to the expected range for octahedral geometry around the central metal ion [23]. Magnetic moment of the $\mathrm{Cu}$ (II) complex, 1.38 BM, is lower than the expected value for the $\mathrm{S}=1 / 2$ system. This may be explained by a $\mathrm{Cu}-\mathrm{Cu}$ interaction in acetate bridging dinuclear complex [24].

FT-IR spectra

FT-IR spectral data of the ligand and the complexes are given in Table 2. The IR spectrum of the ligand showed medium or strong intensity absorption bands at 1644 and $1495 \mathrm{~cm}^{-1}$ assigned to $\mathrm{C}=\mathrm{N}$ and $\mathrm{C}=\mathrm{C}$ stretching modes. The presence of aromatic rings has been identified by their characteristic ring vibrations at $1500-1400,1100-1050$ and $900-700 \mathrm{~cm}^{-1}$ regions. The broad bands between 2900 and $2600 \mathrm{~cm}^{-1}$ in the spectrum of the ligand demonstrate the formation of the $\mathrm{OH} \cdots \mathrm{N}$ intramolecular hydrogen bond between $\mathrm{OH}$ and $\mathrm{N}$ atom of the ligand $[1,25]$.

The broad bands between 3400 and $3500 \mathrm{~cm}^{-1}$ are due to stretching vibrations of $\mathrm{OH}$. Besides, the broad bands between 3000 and $2600 \mathrm{~cm}^{-1}$ are due to the intra- and intermolecular hydrogen bonding because of water molecules in the spectra of the complexes [26]. These bands are especially observed at the spectra of $\mathrm{Fe}(\mathrm{II}), \mathrm{Fe}(\mathrm{III}), \mathrm{Cr}(\mathrm{III}), \mathrm{Co}(\mathrm{II})$ and $\mathrm{Zn}$ (II) complexes. High water content of $\mathrm{Cr}(\mathrm{III})$ complex appears in the IR spectra prominently (very broad bands between 3450 and $2800 \mathrm{~cm}^{-1}$ ). TGA curve of Cr(III) complex confirms this evaluation. The 
strong band at $1644 \mathrm{~cm}^{-1}, v(\mathrm{C}=\mathrm{N})$, in the ligand spectrum is considerably changed in the complexes: This band shifted to the lower wavenumber in the complexes. This indicates that the azomethine nitrogen is coordinated to the metal ions [27]. The $v(\mathrm{C}-\mathrm{O})$ bands of $\mathrm{C}-\mathrm{OH}$ and $\mathrm{C}-\mathrm{O}-\mathrm{CH}_{3}$ groups of the ligand appear between 1200 and $1290 \mathrm{~cm}^{-1}$ as strong or medium bands. In the complexes, the considerable changes at the 1209 and $1286 \mathrm{~cm}^{-1}$ bands showed the phenolic oxygen coordination to the metal ions $(\mathrm{C}-\mathrm{O} \rightarrow \mathrm{M}$ coordination) [28]. In the $\mathrm{Cu}$ (II) complex, the strong bands at 1482 and $1439 \mathrm{~cm}^{-1}$ are may be due to the coordination of the acetate group oxygen atoms as bidentate [29].

Table 2. The FT-IR spectral data of the ligand and the complexes.

\begin{tabular}{|l|l|}
\hline Compound & \multicolumn{1}{|c|}{ Frequency $\left(\mathrm{cm}^{-1}\right)$} \\
\hline $\mathrm{H}_{2} \mathrm{~L}$ & $3433 \mathrm{w}, \mathrm{br}, 3050 \mathrm{~m}, 2955 \mathrm{~m}, 2829 \mathrm{~m}, 2663 \mathrm{~m}, 1644 \mathrm{~s}, 1595 \mathrm{~m}, 1510 \mathrm{~s}, 1428$ \\
& $\mathrm{~m}, 1345 \mathrm{~m}, 1286 \mathrm{~m}, 1252 \mathrm{~m}, 1209 \mathrm{~s}, 1170 \mathrm{~m}, 1066 \mathrm{~m}, 901 \mathrm{~m}, 811 \mathrm{~m}, 750 \mathrm{~m}$, \\
& $731 \mathrm{~m}, 573 \mathrm{~m}, 435 \mathrm{~m}$ \\
\hline$\left[\mathrm{Cr}(\mathrm{L}) \mathrm{Cl}\left(\mathrm{H}_{2} \mathrm{O}\right)_{2}\right] \cdot 4 \mathrm{H}_{2} \mathrm{O}$ & $3168 \mathrm{br}(3450-2800), 1640 \mathrm{~m}, 1606 \mathrm{~s}, 1548 \mathrm{~m}, 1498 \mathrm{~m}, 1440 \mathrm{~m}, 1274 \mathrm{~m}$, \\
& $1253 \mathrm{~m}, 1216 \mathrm{~m}, 1176 \mathrm{~m}, 1084 \mathrm{w}, 967 \mathrm{w}, 915 \mathrm{w}, 863 \mathrm{w}, 740 \mathrm{~m}, 657 \mathrm{~m}, 574$ \\
& $\mathrm{~m}, 540 \mathrm{~m}, 512 \mathrm{~m}, 453 \mathrm{w}$ \\
\hline$\left[\mathrm{Fe}(\mathrm{L})\left(\mathrm{H}_{2} \mathrm{O}\right)_{3}\right]$ & $3597 \mathrm{~m}, 3055 \mathrm{~m}, \mathrm{br}, 2936 \mathrm{~m}, \mathrm{br}, 2763 \mathrm{~m}, \mathrm{br}, 1606 \mathrm{~s}, 1582 \mathrm{~m}, 1545 \mathrm{~m}, 1480 \mathrm{~s}$, \\
& $1431 \mathrm{~s}, 1382 \mathrm{~m}, 1311 \mathrm{~m}, 1275 \mathrm{~s}, 1257 \mathrm{~s}, 1226 \mathrm{~m}, 1118 \mathrm{~m}, 1051 \mathrm{~s}, 1017 \mathrm{~s}, 974$ \\
& $\mathrm{~m}, 838 \mathrm{~m}, 740 \mathrm{~m}, 688 \mathrm{~m}, 581 \mathrm{w}, 424 \mathrm{w}$ \\
\hline$\left[\mathrm{Fe}(\mathrm{L})\left(\mathrm{H}_{2} \mathrm{O}\right)(\mathrm{OH})\right]$ & $3456 \mathrm{~m}, \mathrm{br}, 3289 \mathrm{~m}, 2965 \mathrm{w}, 1596 \mathrm{~m}, 1577 \mathrm{~m}, 1544 \mathrm{~m}, 1479 \mathrm{~s}, 1426 \mathrm{~m}, 1377$ \\
& $\mathrm{~m}, 1309 \mathrm{w}, 1275 \mathrm{~m}, 1260 \mathrm{~s}, 1222 \mathrm{~s}, 1084 \mathrm{w}, 982 \mathrm{w}, 840 \mathrm{~m}, 738 \mathrm{~m}, 689 \mathrm{~m}$, \\
& $587 \mathrm{w}, 535 \mathrm{~m}, 430 \mathrm{w}$ \\
\hline$\left[\mathrm{Co}(\mathrm{HL})_{2}\right] \cdot 2 \mathrm{H}_{2} \mathrm{O}$ & $3388 \mathrm{~m}, \mathrm{br}, 3197 \mathrm{~m}, \mathrm{br}, 3055 \mathrm{~m}, 2963 \mathrm{~m}, 1640 \mathrm{~m}, 1616 \mathrm{~m}, 1548 \mathrm{w}, 1478 \mathrm{~s}$, \\
& $1441 \mathrm{~m}, 1379 \mathrm{w}, 1290 \mathrm{~m}, 1247 \mathrm{~m}, 1219 \mathrm{~s}, 1177 \mathrm{~m}, 1084 \mathrm{w}, 971 \mathrm{w}, 912 \mathrm{w}$, \\
& $863 \mathrm{w}, 740 \mathrm{~m}, 663 \mathrm{w}, 540 \mathrm{w}, 461 \mathrm{w}$ \\
\hline$\left[\mathrm{Ni}(\mathrm{L})\left(\mathrm{H}_{2} \mathrm{O}\right)_{3}\right]$ & $3452 \mathrm{~s}, 3317 \mathrm{~m}, 2926 \mathrm{~m}, \mathrm{br}, 1614 \mathrm{~m}, 1590 \mathrm{~m}, 1548 \mathrm{~m}, 1502 \mathrm{~m}, 1445 \mathrm{~s}, 1392$ \\
& $\mathrm{~m}, 1282 \mathrm{~s}, 1254 \mathrm{~m}, 1224 \mathrm{~s}, 1184 \mathrm{~m}, 1098 \mathrm{~m}, 976 \mathrm{~m}, 924 \mathrm{~m}, 825 \mathrm{~m}, 746 \mathrm{~m}$, \\
& $676 \mathrm{~m}, 606 \mathrm{w}, 531 \mathrm{w}, 462 \mathrm{w}$ \\
\hline$\left[\mathrm{Cu}{ }_{2}(\mathrm{HL})(\mathrm{L})(\mathrm{Ac})\right]$ & $3432 \mathrm{~m}, \mathrm{br}, 3007 \mathrm{w}, 2930 \mathrm{w}, 1608 \mathrm{~s}, 1577 \mathrm{w}, 1540 \mathrm{~m}, 1482 \mathrm{~s}, 1439 \mathrm{~s}, 1386 \mathrm{w}$, \\
& $1281 \mathrm{~m}, 1253 \mathrm{~m}, 1232 \mathrm{~s}, 1080 \mathrm{w}, 985 \mathrm{~m}, 923 \mathrm{w}, 834 \mathrm{~m}, 750 \mathrm{~m}, 689 \mathrm{~m}, 538 \mathrm{~m}$, \\
& $427 \mathrm{w}$. \\
\hline$\left[\mathrm{Zn}(\mathrm{L})\left(\mathrm{H}_{2} \mathrm{O}\right)_{2}\right]$ & $3420 \mathrm{~m}, 3061 \mathrm{~m}, \mathrm{br}, 2936 \mathrm{~m}, \mathrm{br}, 1634 \mathrm{~s}, 1584 \mathrm{~m}, 1542 \mathrm{~m}, 1482 \mathrm{~s}, 1445 \mathrm{~s}, 1392$ \\
& $\mathrm{~m}, 1315 \mathrm{~m}, 1278 \mathrm{~m}, 1245 \mathrm{~m}, 1225 \mathrm{~s}, 1087 \mathrm{w}, 982 \mathrm{~m}, 917 \mathrm{w}, 828 \mathrm{w}, 742 \mathrm{~m}$, \\
& $677 \mathrm{~m}, 522 \mathrm{w}, 403 \mathrm{w}$ \\
\hline $\mathrm{m}=\mathrm{medium}, \mathrm{s}=\mathrm{strong}, \mathrm{sh}=\mathrm{shoulder}, \mathrm{w}=\mathrm{weak}, \mathrm{br}=\mathrm{broad}$.
\end{tabular}

\section{UV-Visible spectra}

The UV-Visible spectral data are given in Table 3. The UV-Visible absorption spectra were obtained in methanol at room temperature. The electronic spectra of the compounds exhibited intense bands in the $200-400 \mathrm{~nm}$ region, which may be assignable to the $n \rightarrow \sigma^{*}, n \rightarrow \pi^{*}$ and $\pi \rightarrow \pi^{*}$ transitions. The bands below $250 \mathrm{~nm}$ are due to the $n \rightarrow \sigma^{*}$ transitions. Schiff base ligands exhibit intense intra-ligand absorption bands in the $250-350 \mathrm{~nm}$ region. The $\pi \rightarrow \pi^{*}$ transitions of the aromatic rings are observed in the $250-300 \mathrm{~nm}$ region whereas the $\pi \rightarrow \pi^{*}$ transitions of the $\mathrm{C}=\mathrm{N}$ bond are in between 300 and $350 \mathrm{~nm}$ [30].

The Cr(III) complex showed three bands at 725 (m,br), 668 (m,br) and $489 \mathrm{~nm}(\mathrm{sh})$ in the UV-visible spectra. These bands are consistent with the octahedral geometry of $\mathrm{Cr}$ (III) complexes. The medium band at $391 \mathrm{~nm}$ is due to LMCT transition [31].

Three bands are observed in the Fe(III) complex at $624(\mathrm{~m}), 554(\mathrm{sh})$ and $513 \mathrm{~nm}(\mathrm{w})$ which do not suggest the octahedral or tetrahedral geometry around the metal atom. These bands may be considered as a support for five coordinate square pyramidal Fe(III) complex [32]. And, the strong absorption at $404 \mathrm{~nm}$ is due to LMCT transition. 
Table 3. The UV-Visible spectral data of the compounds.

\begin{tabular}{|l|l|}
\hline Compound & Wavelength $\left(\lambda_{\max }, \mathrm{nm}\right)$ in MeOH $\left(10^{-4} \mathrm{M}\right)$ \\
\hline $\mathrm{H}_{2} \mathrm{~L}$ & $462 \mathrm{~m}, \mathrm{br}, 353 \mathrm{~m}, \mathrm{br}, 278 \mathrm{~s}, \mathrm{br}, 220 \mathrm{~s}$ \\
\hline$\left[\mathrm{Cr}(\mathrm{L}) \mathrm{Cl}\left(\mathrm{H}_{2} \mathrm{O}\right)_{2}\right] \cdot 4 \mathrm{H}_{2} \mathrm{O}$ & $738 \mathrm{w}, \mathrm{br}, 668 \mathrm{w}, \mathrm{br}, 487 \mathrm{sh}, 462 \mathrm{w}, \mathrm{br}, 392 \mathrm{~m}, \mathrm{br}, 316 \mathrm{~m}, \mathrm{br}, 286 \mathrm{~m}, \mathrm{br}, 227 \mathrm{sh}$, \\
& $211 \mathrm{~s}$ \\
\hline$\left[\mathrm{Fe}(\mathrm{L})\left(\mathrm{H}_{2} \mathrm{O}\right)_{3}\right]$ & $605 \mathrm{w}, 505 \mathrm{~m}, \mathrm{br}, 403 \mathrm{~m}, \mathrm{br}, 297 \mathrm{~m}, 231 \mathrm{~s}$ \\
\hline$\left[\mathrm{Fe}(\mathrm{L})\left(\mathrm{H}_{2} \mathrm{O}\right)(\mathrm{OH})\right]$ & $754 \mathrm{sh}, 624 \mathrm{~m}, 554 \mathrm{sh}, 513 \mathrm{w}, 404 \mathrm{~s}, 299 \mathrm{~s}, 231 \mathrm{~s}$ \\
\hline$\left[\mathrm{Co}(\mathrm{HL})_{2}\right] \cdot 2 \mathrm{H}_{2} \mathrm{O}$ & $462 \mathrm{sh}, 433 \mathrm{~m}, \mathrm{br}, 305 \mathrm{sh}, 262 \mathrm{sh}, 254 \mathrm{~m}, 212 \mathrm{~s}$ \\
\hline$\left[\mathrm{Ni}(\mathrm{L})\left(\mathrm{H}_{2} \mathrm{O}\right)_{3}\right]$ & $459 \mathrm{sh}, 438 \mathrm{~m}, 359 \mathrm{sh}, 342 \mathrm{~m}, 311 \mathrm{sh}, 300 \mathrm{~m}, 248 \mathrm{sh}, 216 \mathrm{~s}$ \\
\hline$\left[\mathrm{Cu}{ }_{2}(\mathrm{HL})(\mathrm{L})(\mathrm{Ac})\right]$ & $752 \mathrm{w}, 457 \mathrm{sh}, 432 \mathrm{~s}, 397 \mathrm{~m}, \mathrm{br}, 326 \mathrm{sh}, 312 \mathrm{~m}, 301 \mathrm{~m}, 253 \mathrm{sh}$ \\
\hline$\left[\mathrm{Zn}(\mathrm{L})\left(\mathrm{H}_{2} \mathrm{O}\right)_{2}\right]$ & $457 \mathrm{sh}, 434 \mathrm{w}, 390 \mathrm{sh}, 299 \mathrm{~m}, \mathrm{br}, 268 \mathrm{~m}, 254 \mathrm{sh}, 213 \mathrm{~s}$ \\
\hline
\end{tabular}

The electronic spectra of the other complexes are of little help in the present case at the visible region, since the $\mathrm{d} \rightarrow \mathrm{d}$ transitions are masked by the strong charge-transfer transition bands [33]. 505, 438 and $433 \mathrm{~nm}$ absorptions for the $\mathrm{Fe}(\mathrm{II}), \mathrm{Ni}(\mathrm{II})$ and $\mathrm{Co}(\mathrm{II})$ complexes, respectively, can be accepted CT transitions. On the other hand, the shoulders at $459 \mathrm{~nm}$ for the $\mathrm{Ni}$ (II) complex and $462 \mathrm{~nm}$ for the Co(II) complex, and the weak absorption at $605 \mathrm{~nm}$ in the $\mathrm{Fe}(\mathrm{II})$ complex may be related with their octahedral structures [23, 34].

There is no sufficient information from electronic spectra of the $\mathrm{Cu}$ (II) and $\mathrm{Zn}$ (II) complexes. The absorptions of the both complexes at the $430-460 \mathrm{~nm}$ range are due to the CT transitions. The weak band at $752 \mathrm{~nm}$ in the $\mathrm{Cu}$ (II) complex is due to the $\mathrm{d}-\mathrm{d}$ transitions and can be considered as indicative of a tetragonal environment for the metal ion and in agreement with the values obtained for dimeric $\mathrm{Cu}(\mathrm{II})$ complexes [35].

NMR spectra

The ${ }^{1} \mathrm{H}-\mathrm{NMR}$ spectral data of the ligand and its' $\mathrm{Zn}$ (II) complex are given in Table 4. The ligand has two hydroxyl protons: $\mathrm{OH}-2$ and $\mathrm{OH}-2$ ' (Figure 2). The $\mathrm{OH}-2$ ' proton of the salicylaldimine moiety (phenolic proton) appeared at $13.64 \mathrm{ppm}$ as a broad singlet and $\mathrm{OH}-2$ proton of chlorohydroxyphenyl at $10.00 \mathrm{ppm}$ as singlet. According to the above observation, it may be estimated that $\mathrm{OH}-2$ ' (phenolic) proton will be removed firstly on complexation. Removing of the second proton is unlikely in 1:2 M:L complex, namely Co(II) complex, with regard to electroneutrality. The both $\mathrm{OH}$ protons disappear on complexation with the $\mathrm{Zn}(\mathrm{II})$ ion.

The azomethine proton of the ligand and $\mathrm{Zn}(\mathrm{II})$ complex appeared at 8.96 and $8.87 \mathrm{ppm}$, respectively. The upfield shift (shielding) in the $\mathrm{Zn}$ (II) complex shows that the azomethine nitrogen coordinated to $\mathrm{Zn}(\mathrm{II})$ ion [36]. The very broad signal at $6.67 \mathrm{ppm}$ is remarkable in $\mathrm{Zn}$ (II) complex: It may be belongs to H4' proton. This proton appears as a broad signal at the ligand $(7.19 \mathrm{~d}-\mathrm{d}, \mathrm{br})$. This proton gains high acidic character as a result of complexation because of the perturbing effect of $\mathrm{Zn}$ (II) ion. Thus, it appears as a very broad signal and showed upfield shift (lower ppm value). The suggested structure of the $\mathrm{Zn}(\mathrm{II})$ complex is shown in Figure 2.

Table 4. The ${ }^{1} \mathrm{H}-\mathrm{NMR}$ spectral data of the ligand and its $\mathrm{Zn}(\mathrm{II})$ complex $\left(\delta_{\mathrm{H}}\right.$, as ppm, in DMSO- $\left.\mathrm{d}_{6}\right)$.

\begin{tabular}{|c|c|c|c|c|c|c|c|c|c|c|}
\hline \multirow{2}{*}{ Compound } & \multicolumn{4}{|c|}{ Chloro-hydroxyphenyl protons } & \multirow{2}{*}{$\mathrm{C} \underline{\mathrm{H}}=\mathrm{N}$} & \multicolumn{5}{|c|}{ Phenolic (salicylaldimine) protons } \\
\hline & $\mathrm{H} 3$ & $\mathrm{H} 4$ & H6 & $\mathrm{OH}(2)$ & & $\mathrm{OH}\left(2^{\prime}\right)$ & $\mathrm{OCH}_{3}$ & $\mathrm{H} 4{ }^{\prime}$ & H5 & H6' \\
\hline $\mathrm{H}_{2} \mathrm{~L}$ & $\begin{array}{l}7.10 \text { dd,br } \\
\mathrm{J}=7.8 ; 1.5\end{array}$ & $\begin{array}{c}7.15 \mathrm{dd} \\
\mathrm{J}=2.6 ; 8.2\end{array}$ & $\begin{array}{l}7.48 \mathrm{~d} \\
\mathrm{~J}=2.6\end{array}$ & $\begin{array}{c}10.0 \\
\mathrm{~s}\end{array}$ & $\begin{array}{c}8.96 \\
\mathrm{~s}\end{array}$ & $\begin{array}{c}13.64 \\
\text { s,br }\end{array}$ & $\begin{array}{c}3.80 \\
\mathrm{~s}\end{array}$ & $\begin{array}{c}7.19 \text { dd, br } \\
\mathrm{J}=1.3 ; \\
8.0\end{array}$ & $\begin{array}{c}6.87 \mathrm{t} \\
\mathrm{J}=8.3 \\
7.8\end{array}$ & $\begin{array}{l}6.95 \mathrm{~d} \\
\mathrm{~J}=8.8\end{array}$ \\
\hline$\left[\mathrm{Zn}(\mathrm{L})\left(\mathrm{H}_{2} \mathrm{O}\right)_{2}\right]$ & $\begin{array}{c}6.91 \mathrm{~d} \\
\mathrm{~J}=7.32\end{array}$ & $\begin{array}{c}6.97 \mathrm{~d} \\
\mathrm{~J}=7.35\end{array}$ & $7.57 \mathrm{~s}$ & -- & $\begin{array}{c}8.87 \\
\mathrm{~s}\end{array}$ & -- & $\begin{array}{c}3.73 \\
\mathrm{~s}\end{array}$ & $\begin{array}{l}6.67 \\
\text { s,br }\end{array}$ & $\begin{array}{c}6.39 \mathrm{t} \\
\mathrm{J}=7.81 \\
7.80\end{array}$ & $\begin{array}{c}6.81 \mathrm{~d} \\
\mathrm{~J}=7.32\end{array}$ \\
\hline
\end{tabular}




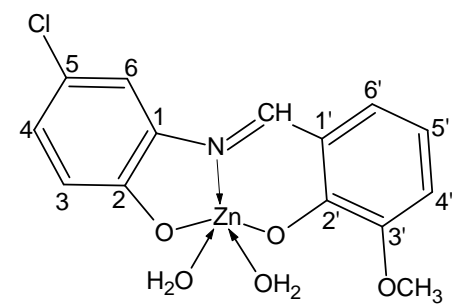

Figure 2. The suggested structure of the $\mathrm{Zn}(\mathrm{II})$ complex.

\section{Mass spectra}

The ESI-MS spectral data of the complexes are given in Table 5 as molecular ions with the relative abundance. It is known that chlorine, bromine and copper have two isotopes: These isotopes, their percent abundance and approximately relative proportions are as the following: ${ }^{35} \mathrm{Cl}(75.8 \%):{ }^{37} \mathrm{Cl}(24.2 \%)(3: 1) ;{ }^{79} \mathrm{Br}(50.7 \%):{ }^{81} \mathrm{Br}(49.3 \%)(1: 1) ;{ }^{63} \mathrm{Cu}(69.2 \%):{ }^{65} \mathrm{Cu}(30.8 \%)(2: 1)$. On the other hand, $\mathrm{Cr}, \mathrm{Fe}, \mathrm{Zn}$ and $\mathrm{Ni}$ have various isotopes whereas $\mathrm{Co}$ has only one isotope. Because of all these reasons, there are many mole peaks at the mass spectra of the complexes. Besides, the peaks of the ligand are easily determined in the mass spectra of the $\mathrm{Fe}(\mathrm{III}), \mathrm{Ni}$ (II) and $\mathrm{Zn}(\mathrm{II})$ complexes. The ligand is shown as $\mathrm{L}$ in Table 5 .

Table 5. The ESI-MS spectral data of the compounds.

\begin{tabular}{|l|l|}
\hline $\begin{array}{l}\text { Compound and } \\
\mathrm{MW}(\mathrm{g} / \mathrm{mol})\end{array}$ & Molecular ions $(\mathrm{m} / \mathrm{z})$ with relative abundance $(\%)$ and isotopic patterns \\
\hline $\mathrm{H}_{2} \mathrm{~L}$ & $276.77\left(100,[\mathrm{M}-1]^{+}\left\{\left\{^{35} \mathrm{Cl}\right\}\right), 277.78\left(39.2,[\mathrm{M}]^{+}\left\{^{35} \mathrm{Cl}\right\}\right)\right.$, \\
277.5 & $278.71\left(86.3,[\mathrm{M}+1]^{+}\left\{{ }^{35} \mathrm{Cl}+{ }^{37} \mathrm{Cl}\right\}\right), 279.98\left(16.1,[\mathrm{M}+2]^{+}\left\{{ }^{37} \mathrm{Cl}\right\}\right)$ \\
\hline$\left[\mathrm{Cr}(\mathrm{L}) \mathrm{Cl}\left(\mathrm{H}_{2} \mathrm{O}\right)_{2}\right] \cdot 4 \mathrm{H}_{2} \mathrm{O}$ & $467.7\left(14.2,[\mathrm{M}-3]^{+}\right), 468.8\left(16.4,[\mathrm{M}-2]^{+}\right), 470.9\left(11.9, \mathrm{M}^{+}\right), 417.9(21.7,[\mathrm{M}-$ \\
471.1 & $\left.\left.3 \mathrm{H}_{2} \mathrm{O}\right]\right), 422.9\left(100,\left[\mathrm{M}-3 \mathrm{H}_{2} \mathrm{O}+5\right]\right)$, \\
\hline$\left[\mathrm{Fe}(\mathrm{L})\left(\mathrm{H}_{2} \mathrm{O}\right)_{3}\right] \cdot \mathrm{H}_{2} \mathrm{O}$ & $401.2\left(100,[\mathrm{M}-2]^{+}\right), 403.2\left(82.5,[\mathrm{M}]^{+}\right), 405.2\left(27.6,[\mathrm{M}+2]^{+}\right), 365.8(17.5$, \\
403.6 & $\left.\left[\mathrm{~L}+\mathrm{Fe}+2 \mathrm{H}_{2} \mathrm{O}\right]\right)$ \\
\hline$\left[\mathrm{Fe}(\mathrm{L})\left(\mathrm{H}_{2} \mathrm{O}\right)(\mathrm{OH})\right]$ & $365.0\left(100,[\mathrm{M}-2]^{+}\right), 367.0\left(88.6, \mathrm{M}^{+}\right), 369.0\left(29.5,[\mathrm{M}+2]^{+}\right), 278.3(42.6, \mathrm{~L})$ \\
366.6 & \\
\hline$\left[\mathrm{Co}(\mathrm{HL})_{2}\right] \cdot 2 \mathrm{H}_{2} \mathrm{O}$ & $609.2\left(100,\left[\mathrm{M}-2 \mathrm{H}_{2} \mathrm{O}-3\right]\right), 611.2\left(65.7,\left[\mathrm{M}-2 \mathrm{H}_{2} \mathrm{O}-1\right]\right), 610.2\left(28.9,\left[\mathrm{M}-2 \mathrm{H}_{2} \mathrm{O}-\right.\right.$ \\
648.35 & $2]), 612.2\left(18.0,\left[\mathrm{M}-2 \mathrm{H}_{2} \mathrm{O}\right]\right)$ \\
\hline$\left[\mathrm{Ni}(\mathrm{L})\left(\mathrm{H}_{2} \mathrm{O}\right)_{3}\right]$ & $384.5\left(100,[\mathrm{M}-4]^{+}\right), 386.6\left(26.4,[\mathrm{M}-2]^{+}\right), 387.5\left(10.1,[\mathrm{M}-1]^{+}\right), 388.3(3.6$, \\
388.14 & $\left.[\mathrm{M}]^{+}\right), 276.2(44.1, \mathrm{~L}-2), 278.2(11.4, \mathrm{~L})$ \\
\hline$\left[\mathrm{Cu}{ }_{2}(\mathrm{HL})(\mathrm{L})(\mathrm{Ac})\right]$ & $737.4\left(25.1,[\mathrm{M}-2]^{+}\right), 736.5\left(22.3,[\mathrm{M}-1]^{+}\right), 739.4\left(19.4,[\mathrm{M}]^{+}\right), 675.8(100$, \\
738.6 & $\left.\left[\mathrm{M}-\mathrm{Ac}-\mathrm{H}_{2} \mathrm{O}\right]\right)$ \\
\hline$\left[\mathrm{Zn}(\mathrm{L})\left(\mathrm{H}_{2} \mathrm{O}\right)_{2}\right]$ & $376.1\left(12.1,[\mathrm{M}-1]^{+}\right), 358.0\left(15.3,\left[\mathrm{M}-\mathrm{H}_{2} \mathrm{O}\right]^{+}\right), 339.4\left(20.2,\left[\mathrm{M}-2 \mathrm{H}_{2} \mathrm{O}\right]\right), 278.4$ \\
377.1 & $\left(42.2,[\mathrm{~L}+1]^{+}\right), 606.2\left(100,\left[2 \mathrm{~L}+\mathrm{Zn}+\mathrm{H}_{2} \mathrm{O}\right]\right)$ \\
\hline
\end{tabular}

Thermal analysis

The major features of the thermal analysis of the complexes are summarized in Table 6 . The thermal analysis curves are shown in Figures 3 and 4. The samples of the complexes were heated from room temperature up to $800^{\circ} \mathrm{C}$. Thermal degradation of complexes occurred in three stages. At the first stage, uncoordinated lattice water was lost through evaporation from 50 to $100{ }^{\circ} \mathrm{C}$. At the second stage, the coordinated water molecules are removed from $\mathrm{Cr}$ (III), $\mathrm{Fe}(\mathrm{II})$, $\mathrm{Fe}(\mathrm{III})$ and $\mathrm{Zn}$ (II) complexes at temperatures between 100 and $200{ }^{\circ} \mathrm{C}$. $\mathrm{Cr}$ (III) complex has coordinated and uncoordinated water molecules according to the analytical and thermal analysis data. TGA values are compatible with the suggested structures of the complexes. TGA curve of $\mathrm{Co}(\mathrm{II})$ complex draws attention different from the others because of its' 1:2 M:L ratio and 
different coordination. Molecular weight ratio of the amount of metal oxide show very good agreement for the proposed structures according to the TGA data. In the all complexes, weight losses observed above $300{ }^{\circ} \mathrm{C}$ can be explained in terms of cleavage of $\mathrm{Cl}, \mathrm{OH}$ and $\mathrm{OCH}_{3}$ groups. Above $350{ }^{\circ} \mathrm{C}$, all other organic parts of complexes are oxidized to carbon dioxide and water.

Table 6. The TGA data of the complexes (thermal decomposition).

\begin{tabular}{|l|l|l|l|l|l|l|l|l|l|l|l|}
\hline \multicolumn{1}{|c|}{ Temperature $\left({ }^{\circ} \mathrm{C}\right) \rightarrow$} & 100 & 150 & 200 & 250 & 300 & 350 & 400 & 450 & 500 & 550 \\
\hline Complex & \multicolumn{7}{|c|}{ Weight loss $(\%)$} \\
\hline$\left[\mathrm{Cr}(\mathrm{L}) \mathrm{Cl}\left(\mathrm{H}_{2} \mathrm{O}\right)_{2}\right] \cdot 4 \mathrm{H}_{2} \mathrm{O}$ & 9.3 & 15.2 & 23.6 & 29.3 & 32.6 & 67.0 & 84.0 & 85.2 & 85.1 & 85.1 \\
\hline$\left[\mathrm{Fe}(\mathrm{L})\left(\mathrm{H}_{2} \mathrm{O}\right)_{3}\right]$ & 2.6 & 3.3 & 4.4 & 9.4 & 9.6 & 11.3 & 80.3 & 81.2 & 81.9 & 81.7 \\
\hline$\left[\mathrm{Fe}(\mathrm{L})\left(\mathrm{H}_{2} \mathrm{O}\right)(\mathrm{OH})\right]$ & 1.2 & 2.2 & 6.6 & 7.0 & 7.5 & 78.7 & 80.1 & 80.3 & 82.6 & 82.5 \\
\hline$\left[\mathrm{Co}(\mathrm{HL})_{2}\right] \cdot 2 \mathrm{H}_{2} \mathrm{O}$ & 5.9 & 6.7 & 8.2 & 27.5 & 31.8 & 35.3 & 38.4 & 42.9 & 62.0 & 89.9 \\
\hline$\left[\mathrm{Ni}(\mathrm{L})\left(\mathrm{H}_{2} \mathrm{O}\right)_{3}\right]$ & 2.1 & 3.6 & 11.3 & 27.1 & 39.5 & 45.1 & 54.7 & 61.5 & 78.9 & 78.6 \\
\hline$\left[\mathrm{Cu}_{2}(\mathrm{HL})(\mathrm{L})(\mathrm{Ac})\right]$ & 0.4 & 0.5 & 1.0 & 2.1 & 18.9 & 69.4 & 71.5 & 75.9 & 78.4 & 83.4 \\
\hline$\left[\mathrm{Zn}(\mathrm{L})\left(\mathrm{H}_{2} \mathrm{O}\right)_{2}\right]$ & 0.8 & 6.8 & 9.2 & 9.9 & 10.8 & 17.1 & 53.3 & 61.2 & 72.0 & 76.5 \\
\hline
\end{tabular}

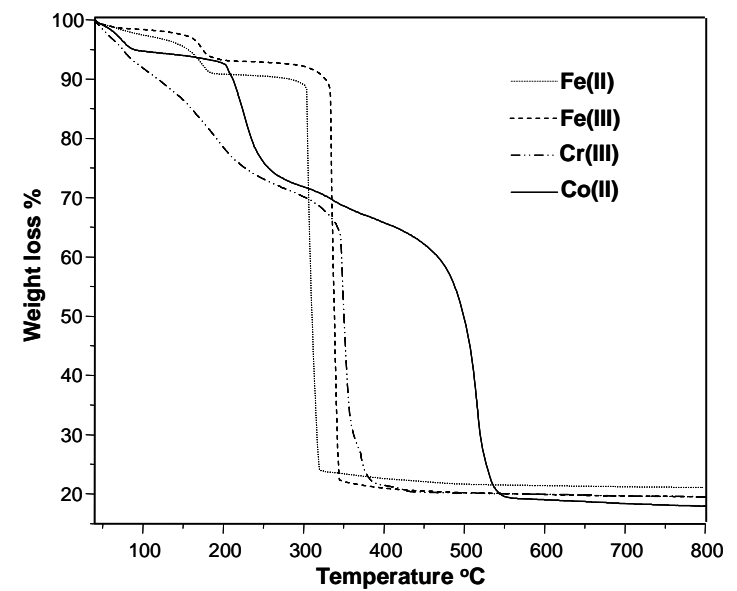

Figure 3. The TGA curves of the Fe(II), Fe(III), Cr(III) and Co(II) complexes.

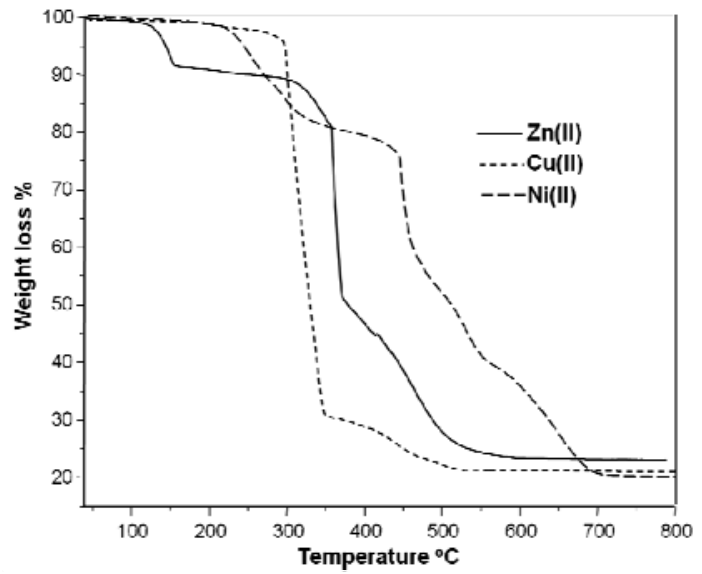

Figure 4. The TGA curves of the $\mathrm{Zn}(\mathrm{II}), \mathrm{Cu}(\mathrm{II})$ and Ni(II) complexes.

Bull. Chem. Soc. Ethiop. 2015, 29(1) 
As a conclusion, according to the experimental data, the structures in Figure 5 can be proposed for the complexes as a conclusion.

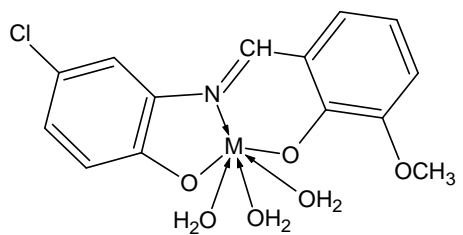

$\mathrm{M}=\mathrm{Fe}(\mathrm{II}), \mathrm{Ni}(\mathrm{II})$

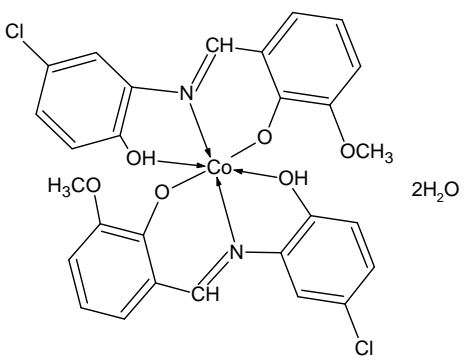<smiles>COc1cccc2c1OP1(O)(O)Oc3ccc(Cl)cc3N=C21</smiles>

$\mathrm{Cl}$<smiles>CCO[C@@]12Oc3ccc(Cl)cc3N1C=Cc1cccc(OC)c1O2</smiles><smiles>CCO[C@]12Oc3ccc(Cl)cc3N1Cc1cccc(OC)c1O2</smiles><smiles>COc1cccc2c1O[C@@]1(O)C=CN2c2cc(Cl)ccc2O1</smiles>

Figure 5. The proposal structures for the $\mathrm{Cr}(\mathrm{III}), \mathrm{Fe}(\mathrm{II}), \mathrm{Fe}(\mathrm{III}), \mathrm{Co}(\mathrm{II}), \mathrm{Ni}(\mathrm{II})$ and $\mathrm{Cu}(\mathrm{II})$ complexes.

\section{Antimicrobial activity}

The antibacterial activities of the free ligand and the complexes were evaluated using the microbroth dilution method toward six bacteria, and the results are compared with those of Ciprofloxacin. Antifungal activities were referenced against Fluconazole. The antimicrobial activity results were presented in Table 7 . Table 7 contains $S$. epidermidis and C. albicans as microorganisms because of some of the compounds showed antimicrobial activity toward these two microorganisms only.

From antimicrobial activity tests the significant results were obtained. The Ni(II), Co(II), $\mathrm{Cr}(\mathrm{III})$ and $\mathrm{Zn}$ (II) complexes are effective on some microorganisms whereas the ligand itself and its $\mathrm{Fe}(\mathrm{II}), \mathrm{Fe}(\mathrm{III})$ and $\mathrm{Cu}(\mathrm{II})$ complexes has no activity on the microorganisms. The $\mathrm{Co}(\mathrm{II})$ and $\mathrm{Ni}(\mathrm{II})$ complexes exhibit considerable antimicrobial activity on $S$. epidermidis and $C$. albicans (MIC value of the Co(II) complex on S. epidermidis $12.5 \mu \mathrm{g} / \mathrm{mL}$; MIC value of the $\mathrm{Ni}$ (II) complex on $C$. albicans $31.2 \mu \mathrm{g} / \mathrm{mL}$ ). These results can be considered as selective activity. In addition, the $\mathrm{Zn}(\mathrm{II})$ complex is effective on $C$. albicans and the $\mathrm{Cr}(\mathrm{III})$ complex 
shows antibacterial activity on $S$. epidermidis selectively. The activity of the Co(II) complex can be explained with its dissociation in DMSO; the dissociation of the Co(II) complex can be interpreted as a factor increasing the antimicrobial activity. The antifungal activity of the Ni(II) complex may be related with its coordinated water content. In the Ni(II) complex three moles of water were coordinated to the central atom. Water is a weak ligand and it cannot compete the DNA of the microorganisms, and consequently they leave the Ni(II) ion and the microorganisms may coordinated to the central atom instead of the water molecules. This evaluation may also be suggested for the $\mathrm{Cr}$ (III) and $\mathrm{Zn}$ (II) complexes that contain three and two coordinated water molecules, respectively. As a result, the moderate antimicrobial activities of the $\mathrm{Ni}(\mathrm{II}), \mathrm{Co}(\mathrm{II})$, $\mathrm{Zn}(\mathrm{II})$ and $\mathrm{Cr}(\mathrm{III})$ complexes against $S$. epidermidis and $C$. albicans warranted further investigation on similar compounds.

Table 7. The in vitro antimicrobial activity of the complexes (MIC, $\mu \mathrm{g} / \mathrm{mL})^{*}$.

\begin{tabular}{|c|c|c|}
\hline \multirow{2}{*}{ Compound } & \multicolumn{2}{|c|}{ Microorganisms } \\
\hline & $\mathrm{Se}$ & $\mathrm{Ca}$ \\
\hline $\mathrm{H}_{2} \mathrm{~L}$ & - & - \\
\hline$\left[\mathrm{Cr}(\mathrm{L}) \mathrm{Cl}\left(\mathrm{H}_{2} \mathrm{O}\right)_{2}\right] \cdot 4 \mathrm{H}_{2} \mathrm{O}$ & 156 & - \\
\hline$\left[\mathrm{Fe}(\mathrm{L})\left(\mathrm{H}_{2} \mathrm{O}\right)_{3}\right]$ & - & - \\
\hline$\left[\mathrm{Fe}(\mathrm{L})\left(\mathrm{H}_{2} \mathrm{O}\right)(\mathrm{OH})\right]$ & - & - \\
\hline$\left[\mathrm{Co}(\mathrm{HL})_{2}\right] \cdot 2 \mathrm{H}_{2} \mathrm{O}$ & 12.5 & 39 \\
\hline$\left[\mathrm{Ni}(\mathrm{L})\left(\mathrm{H}_{2} \mathrm{O}\right)_{3}\right]$ & 156 & 31.2 \\
\hline$\left[\mathrm{Cu}_{2}(\mathrm{HL})(\mathrm{L})(\mathrm{Ac})\right]$ & - & - \\
\hline$\left[\mathrm{Zn}(\mathrm{L})\left(\mathrm{H}_{2} \mathrm{O}\right)_{2}\right]$ & - & 312 \\
\hline Ciprofloxacin & 0.0625 & - \\
\hline Fluconazole & - & 1.00 \\
\hline
\end{tabular}

Se: Staphylococcus epidermidis ATCC 12228. Ca: Candida albicans ATCC 10231. -: Antimicrobial activity was not detected. * Only two microorganisms that affected by the compounds under study were showed.

\section{CONCLUSIONS}

Salicylaldehyde derivatives, with one or more halo-atoms in the aromatic ring, showed variety of biological activities such as antibacterial and antifungal activities. In this study, Cr(III), $\mathrm{Fe}(\mathrm{II}), \mathrm{Fe}(\mathrm{III}), \mathrm{Co}(\mathrm{II}), \mathrm{Ni}(\mathrm{II}), \mathrm{Cu}(\mathrm{II}), \mathrm{Zn}$ (II) complexes of $\mathrm{N}$-(5-chloro-2-hydroxyphenyl)-3methoxy-salicylaldimine $\left(\mathrm{H}_{2} \mathrm{~L}\right)$ were prepared and characterized by elemental analysis, magnetic moment, molar conductivity, TGA and NMR, IR, UV-Vis and ESI-MS spectral techniques. It is observed that all of the complexes except $\left[\mathrm{Zn}(\mathrm{L})\left(\mathrm{H}_{2} \mathrm{O}\right)_{2}\right]$ are paramagnetic. The $\mathrm{CoCl}_{2}$ gave a complex with 1:2 M:L ratio while the others form 1:1 non-ionic complexes with $\mathrm{H}_{2} \mathrm{~L} . \mathrm{H}_{2} \mathrm{~L}$, an ONO type ligand, acts tridentate behaviour coordinating to the metal ions through the both $\mathrm{OH}$ oxygen and the azomethine nitrogen atoms. Considering the magnetic moment values and the electronic spectral data, octahedral geometry is proposed for the $\mathrm{Fe}(\mathrm{II}), \mathrm{Cr}$ (III), $\mathrm{Co}(\mathrm{II}), \mathrm{Ni}(\mathrm{II})$ complexes. The $\mathrm{Zn}$ (II) and $\mathrm{Fe}(\mathrm{III})$ complexes have five coordination geometries whereas the $\mathrm{Cu}$ (II) complex is four-coordinated having acetato bridged dimeric structure. Antibacterial activities of the compounds were determined by the microbroth dilution technique against Staphylococcus aureus, Staphylococcus epidermidis, Escherichia coli, Klebsiella pneumoniae, Pseudomonas aeruginosa, Proteus mirabilis. Antifungal activities were reported for Candida albicans. It is observed that $\mathrm{Ni}$ (II) and $\mathrm{Co}(\mathrm{II})$ complexes exhibit considerable activity on $S$. epidermidis and $C$. albicans whereas the ligand has no activity on the microorganisms. In addition, the $\mathrm{Cr}$ (III) complex shows antibacterial activity toward $S$. epidermidis and the $\mathrm{Zn}$ (II) complex has antifungal activity on C. albicans. 


\section{ACKNOWLEDGEMENT}

This work was supported by the Research Fund of Istanbul University. Project number: 1519.

\section{REFERENCES}

1. a) Çinarli, A.; Gürbüz, D.; Tavman, A.; Birteksöz, A.S. Bull. Chem. Soc. Ethiop. 2011, 25, 407; b) Çinarli, A.; Gürbüz, D.; Tavman, A; Birteksöz, A.S. Chinese J. Chem. 2012, 30, 449; c) Gürbüz, D.; Çinarli, A.; Tavman, A.; Birteksöz, A.S. Chinese J. Chem. 2012, 30, 970; d) Tavman, A. Anal. Sci. 2008, 24, x145.

2. a) Popovic, Z.; Pavlovic, G.; Matkovic-Calogovis, D.; Roje, V.; Leban, I. J. Mol. Struct. 2002, 615, 23; b) Elmali, A.; Elerman, Y.; Svoboda, I. Acta Cryst. 2001, C54, 485; c) Ünver, H.; Karakaş, A.; Elmali, A. J. Mol.Struct. 2008, 877, 152.

3. You, Z.-L.; Zhu, H.-L.; Liu, W.-S. Z. Anorg. Allg. Chem. 2004, 630, 1617.

4. You, Z.-L.; Zhu, H.-L. Z. Anorg. Allg. Chem. 2004, 630, 2754.

5. Gölcü, A.; Tümer, M.; Demirelli, H.; Wheatley, R.A. Inorg. Chim. Acta 2005, 358, 1785.

6. Chandra, S.; Sangeetika, X. Spectrochim. Acta 2004, A60, 147.

7. a) Fujita, E.; Brunschwig, B.S.; Ogata, T.; Yanagida, S. Coord. Chem. Rev. 1994, 132, 195; b) Kimura, E.; Wada, S.; Shiyonoya, M.; Okazaki, Y. Inorg. Chem. 1994, 33, 770; c) De Clercq, B.; Verpoort, F. Macromolecules 2002, 35, 8943; d) Opstal, T.; Verpoort, F. Angew. Chem. Int. Ed. 2003, 42, 2876; e) De Clercq, B.; Lefebvre, F.; Verpoort, F. Appl. Catal. 2003, A247, 345.

8. a) Ren, S.; Wang, R.; Komatsu, K.; Bonaz-Krause, P.; Zyrianov, Y.; McKenna, C.E.; Csipke, C.; Tokes, Z.A.; Lien, E.J. J. Med. Chem. 2002, 45, 410; b) Hodnett, E.M.; Dunn, W.J. J. Med. Chem. 1970, 13, 768.

9. a) Yang, Z.-Y.; Yang, R.-D.; Li, F.-S.; Yu, K.-B. Polyhedron 2000, 19, 2599; b) Chakraborty, J.; Patel, R.N. J. Ind. Chem. Soc. 1996, 73, 191; c) Zhong, X.; Yi, J.; Sun, J.; Wei, H.-L.; Liu, W.-S.; Yu, K.-B. Eur. J. Med. Chem. 2006, 41, 1090; d) Adsule, S.; Barve, V.; Chen, D.; Ahmed, F.; Dou, Q.P.; Padhye, S.; Sarkar, F.H. J. Med. Chem. 2006, 49, 7242.

10. Majumder, A.; Rosair, G.M.; Mallick, A.; Chattopadhyay, N. Polyhedron 2006, 25, 1753.

11. Zishen, W.; Zhiping, L.; Zhenhuan, Y. Transit. Met. Chem. 1993, 18, 291.

12. a) Khalil, M.M.H.; Aboaly, M.M.; Ramadan, R.M. Spectrochim. Acta 2005, A61, 157; b) Chantarasiri, N.; Ruangpornvisuti, V.; Muangsin, N.; Detsen, H.; Mananunsap, T.; Batiya, C.; Chaichit, N. J. Mol. Struct. 2004, 701, 93; c) Abdallah, S.M.; Mohamed, G.G.; Zayed, M.A.; El-Ela, M.S.A. Spectrochim. Acta 2009, A73, 833.

13. a) Radhakrishanan, P.K.; Indrasen, P.; Nair, C.G.R. Polyhedron 1998, 18, 67; b) Ispir, E.; Kurtoglu, M.; Purtas, F.; Serin, S. Transit. Met. Chem. 2005, 30, 1042; c) Sreedaran, S.; Bharathi, K.S.; Kalilur-Rahiman, A.; Rajesh, K.; Nirmala, G.; Jagadish, L.; Kaviyarasan, V.; Narayana, V. Polyhedron 2008, 27, 1867.

14. Clinical and Laboratory Standards Institute (CLSI) Methods for dilution antimicrobial susceptibility tests for bacteria that grow aerobically, Approved Standard M7-A5, Wayne: PA, USA; 2006.

15. Clinical and Laboratory Standards Institute (CLSI) Reference method for broth dilution antifungal susceptibility testing of yeasts, Approved Standart M27-A2, 2nd ed., Wayne: PA, USA; 2002.

16. a) Sanchiz, J.; Esparza, P.; Dominguez, S.; Brito, F.; Mederos, A. Inorg. Chim. Acta 1999, 291, 158; b) Türkel, N.; Aydin, R.; Özer, U. Turk. J. Chem. 1999, 23, 249; c) Kopecka, B.; Springer, V.; Majer, J. Chem. Zvesti. 1981, 35, 641.

17. a) Wahlgren, C.G.; Addison, A.W.; Burman, S.; Thompson, L.K.; Sinn, E.; Rowe, T.M. Inorg. Chim. Acta 1989, 166, 59; b) Tavman, A.; Agh-Atabay, N.M.; Güner, S.; Gücin, F.; 
Dülger, B. Transit. Met. Chem. 2007, 32, 172; c) Tavman, A.; Boz, I.; Birteksöz, A.S.; Cinarli, A. J. Coord. Chem. 2010, 63, 1398.

18. a) El-Sawaf, A.K.; West, D.X.; El-Saied, F.A.; El-Bahnasawy, R.M. Transit. Met. Chem. 1998, 23, 565; b) Padhye, S.; Kauffman, G.B. Coord. Chem. Rev. 1985, 63, 127; c) Tavman, A.; Agh-Atabay, N.M.; Neshat, A.; Gücin, F.; Dülger, B.; Haciu, D. Transit. Met. Chem. 2006, 31, 194.

19. Ruminski, R.R.; Nelson, J.; Culver, W. Inorg. Chim. Acta 2004, 357, 839.

20. Shukla, D.; Gupta, L.K.; Chandra, S. Spectrochim. Acta 2008, A71, 746.

21. a) Vinuelas-Zahinos, E.; Maldonado-Rogado, M.A.; Luna-Giles, F.; Barros-Garcia, F.J. Polyhedron 2008, 27, 879; b) Avaji, P.G.; Patil, S.A.; Badami, P.S. Transit. Met. Chem. 2008, 33, 275.

22. a) Sonmez, M. Turk. J. Chem. 2001, 25, 181; b) Anacona, J. R.; Gomez, J. J. Chil. Chem. Soc. 2008, 53, 1694.

23. Jacob, W.; Mukherjee, R. Inorg. Chim. Acta 2006, 359, 4565.

24. a) Nawar, N.A.; Shallaby, A.-H. M.; Hosny, N. M.; Mostafa, M.M. Transit. Met. Chem. 2001, 26, 180; b) Drew, M.G.B.; Yates, P.C. Inorg. Chim. Acta 1986, 118, 37.

25. a) Yildiz, M.; Kiliç, Z.; Hökelek, T. J. Mol. Struct. 1998, 441, 1; b) Schilf, W.; SzadyChelmieniecka, A.; Grech, E.; Przybylski, P.; Brzezinski, B. J. Mol. Struct. 2002, 643, 115.

26. Redshaw, C., Wilkinson, G., Bates, B.H., Hursthouse, M.B. J. Chem. Soc. Dalton Trans. 1992, 1803.

27. a) Koley, M.K.; Sivasubramanian, S.C.; Varghese, B.; Manoharan, P.T.; Koley, A.P. Inorg. Chim. Acta 2008, 361, 1485; b) Purohit, S.; Koley, A.P.; Prasad, L.S.; Manoharan, P.T.; Ghosh, S. Inorg. Chem. 1989, 28, 3735.

28. a) Kaya, İ.; Moral, F.; Özdemir, E. Bull. Chem. Soc. Ethiop. 2009, 23, 55; b) Anitha, C.; Sheela, C.D.; Tharmaraj, P.; Hema, V.V. J. Chem. 2013, in press, http://dx.doi.org/10.1155/2013/724163.

29. a) Yilmaz, V.T.; Hamamci, S.; Andaç, O.; Güven, K. Z. Anorg. Allg. Chem. 2003, 629, 172; b) Dianu, M.L.; Kriza, A.; Stanica, N.; Musuc, A. M. J. Serb. Chem. Soc. 2010, 75, 1515.

30. a) Akkus, Ö.; Uzman, S. Spect. Lett. 2000, 33, 445; b) Ambroziak, K.; Rozwadowski, Z.; Dziembowska, T.; Bieg, B. J. Mol. Struct. 2002, 615, 109; c) Issa, R.M.; Khedr, A.M.; Rizk, H.F. Spectrochim. Acta 2005, A62, 621; d) Habibi, M.H.; Montazerozohori, M.; Lalegani, A.; Harrington, R.W.; Clegg, W. J. Fluorine Chem. 2006, 127, 769.

31. a) Maples, D.L.; Maples, R.D.; Hoffert, W.A.; Parsell, T.H.; van Asselt, A.; Silversides, J.D.; Archibald, S.J.; Hubin, T.J. Inorg. Chim. Acta 2009, 362, 2084; b) Wright-Garcia, K.; Basinger, J.; Williams, S.; Hu, C.J.; Wagenknecht, P.S. Inorg. Chem. 2003, 42, 4885.

32. a) Singh, D.P.; Kumar, R.; Singh, J. Eur. J. Med. Chem. 2009, 44, 1731; b) Lever, A.B.P. Inorganic Electronic Spectroscopy, Elsevier: Amsterdam; 1984.

33. Salem, N.M.H.; El-Sayed, L.; Iskander, M.F. Polyhedron 2008, 27, 3215.

34. Cotton, F.A.; Wilkinson, G.; Murillo, C.A.; Bochmann, M. Advanced Inorganic Chemistry, 6th ed., Wiley: New York; 1999.

35. a) Rodriguez-Infante, C.; Esteban, D.; Avecilla, F.; de Blas, A.; Rodriguez-Blas, T.; Mahia, J.; Macedo, A.L.; Geraldes, C.F.G.C. Inorg. Chim. Acta 2001, 317, 190; b) Piu, P.; Leoni, V.; Zoroddu, M.A.; Manca, G.; Deiana, S.; Gessa, C. Transit. Met. Chem. 1992, 17, 283; c) Alves, W.A.; de Almeida-Filho, S.A.; de Almeida Santos, R.H.; Paduan-Filho, A.; da Costa Ferreira, A.M. J. Braz. Chem. Soc. 2004, 15, 872.

36. a) Montazerozohori, M.; Yadegari, S.; Naghiha, A.; Veyseh, S. J. Ind. Eng. Chem. 2014, 20, 118; b) Montazerozohori, M.; Zahedi, S.; Naghiha, A.; Zohour, M.M. Mater. Sci. Eng. C Mater. Biol. Appl. 2014, 35, 195. 